\title{
Złudne nieuwikłanie. III Rzesza w interpretacji antyfaszystowskiej — casus NRD
}

Antyfaszyzm to termin niejednoznaczny, za którym kryje się wielość funkcji i znaczeń. Bywa odmiennie interpretowany w zależności od określonego momentu historycznego, perspektywy danego narodu czy klasy społecznej. Egalitarny charakter antyfaszyzmu mas robotniczych różni się znacząco od zindywidualizowanego, elitarnego w swojej istocie antyfaszyzmu intelektualistów bądź nieformalnych grup. Inaczej kształtowały się jego dzieje w międzywojniu, jeszcze inaczej po 1945 r. Odrębną specyfikę mają antyfaszyzm francuski, brytyjski, niemiecki, jugosłowiański czy włoski. Można również mówić o szerokim ruchu społecznym, łączącym rozmaite ugrupowania lewicowe (komunistów, socjalistów, socjaldemokratów, anarchistów, anarchosyndykalistów itp.), określające się mianem demokratycznych, w walce przeciwko ugrupowaniom uznanym przez nie za faszystowskie (głównie prawicowym, choć niewyłącznie). Taki charakter miały Fronty Ludowe w Hiszpanii i Francji - koalicje tworzone w drugiej połowie lat 30. XX w., którym udało się przezwyciężyć wewnętrzne podziały na lewicy, wygrać wybory i na krótko przejąć władzę. Ochotnicy z ponad 50 krajów w hiszpańskiej wojnie domowej (1936-1939) walczący po stronie republikańskiej umiejętnie połączyli dwie perspektywy: międzynarodową i lokalną. Antyfaszyści niemieccy byli przekonani, że w bitwie nad Ebro czy przy oblężeniu Oviedo w równym stopniu ważą się losy Republiki, co demokratyzmu w samych Niemczech. Podobny był pogląd przedstawicieli pozostałych narodowości ${ }^{1}$. Jak

${ }^{1} \mathrm{O}$ wojnie domowej z perspektywy antyfaszystów/-ek różnych narodowości por. m.in. S. Stein, Mojna wojna w Hiszpanii: Brygady Międzynarodowe - koniec mitu, Kraków 2015; J. McLellan, Antifascism and Memory in East Germany: Remembering the International Brigades 1945-1989, Oxford 2004, T.B. Linhard, Fearless Women in the Mexican Revolution and the Spanish Civil War, Columbia, 2004; R. Baxell, British Volunteers in the Spanish Civil War: The British Battalion in the Internatinal Brigades, London-New York 2004; P.N. Carroll, The Oddyssey of the Abraham Lincoln Brigade: Americans in the Spanish Civil War, Stanford, 1994; V. Navarro, 
zauważa Eric Hobsbawm, z perspektywy późniejszych tragicznych wydarzeń Holokaustu i II wojny światowej, których skala skutecznie przyćmiła wszystko, co nastąpiło przed nimi ${ }^{2}$, rok 1936 - apogeum antyfaszystowskiej jedności ${ }^{3}$ jawi się już co najwyżej jako „prehistoria”4.

Jednakowoż odlegle z dzisiejszego punku widzenia, choć jej finał nastąpił stosunkowo niedawno, przedstawia się specyficzna odmiana antyfaszyzmu w Niemieckiej Republice Demokratycznej (NRD). Jego analiza stanowi oś niniejszego wywodu, ze szczególnym uwzględnieniem cechującej go iluzoryczności oraz roli, jaką odegrał w interpretacji nieodległej przeszłości, w tym fundamentalnych kwestiach ciągłości między NRD a III Rzeszą oraz odpowiedzialności za zbrodnie popełnione w latach 1933-1945. Posługując się zamiennie fałszem, iluzją i negacją, robiąc użytek z wybiórczego podejścia do faktów bądź instrumentalnej ich wykładni, enerdowski antyfaszyzm zanegował je oba. Stąd zasadna zdaje się teza o ułudzie nieuwikłania podtrzymywanej w NRD - a jeszcze wcześniej w radzieckiej strefie okupacyjnej (SBZ), na bazie której powstało to państwo - praktycznie do samego jej końca.

Fascism and Antifascism: Yesterday and Today (Influences of the Spanish Civil War), „Monthly Review" 47(8), Jan 1996, s. 14-16.

2 Alon Cofino przekonująco stwierdza, iż w drugiej połowie XX w. Zagłada Żydów wyparła rewolucję francuską jako zasadniczy punkt odniesienia. Por. A. Cofino, The Holocaust as a Symbolic Manual: The French Revolution, the Holocaust, and Global Memories, [w:] Marking Evil: Holocaust Memory in the Global Age, red. A. Goldberg, H. Hazan, New York-Oxford 2015, s. 56-69.

${ }^{3}$ Geoff Eley pisze w ten sposób również o okresie 1943-1947 — „wyjątkowym momencie w europejskiej historii”, gdy partie komunistyczne, dotychczas spychane na margines polityczny, zyskały szerokie poparcie społeczne w rezultacie ich oporu przeciw faszyzmowi. Poprzez politykę tworzenia tzw. frontów ludowych z pozostałymi przedstawicielami lewicy przejęły one władzę w Europie Wschodniej lub były temu bliskie na Zachodzie (Francja, Włochy, Grecja). Głoszone przez antyfaszystów hasła humanizmu i demokratyzacji, postulowana przez nich konieczność przeprowadzenia głębokich reform społecznych (m.in. progresywna taksacja, poszerzenie zakresu państwa opiekuńczego i własności publicznej, wprowadzenie elementów planowania do gospodarki, prawo wyborcze dla kobiet) przeniknęły do głównego nurtu. W części zostały one zrealizowane, częściowo upozorowane w krajach bloku komunistycznego. W Europie Zachodniej - po zwrocie na prawo, jaki nastąpił w tej części kontynentu po 1947 r. — zostały przejęte przez partie konserwatywne bądź chadeckie i stopniowo wprowadzane w obawie przed „radykałami”. Por. G. Eley, Legacies of Antifascism: Constructing Democracy in Postwar Europe, „New German Critique”, January 1996, z. 67, s. 73-100.

${ }^{4}$ Za A. Rabinbach, Introduction: Legacies of Antifascism, ibidem, s. 14; J. McLellan, op. cit., s. 6. Por. też E. Hobsbawm, Age of Extremes: The Short Twentieth Century, 1914-1991, London 1994, s. 142-177. 
$* * *$

Najprostsza, najczęstsza i w zasadzie jedyna niekontrowersyjna definicja antyfaszyzmu jest taka, iż stanowi on opozycję względem faszyzmu ${ }^{5}$. Jak stwierdza Tony Judt:

Fundamentem antyfaszystowskiej retoryki stosowanej przez oficjalną lewicę był prosty, dychotomiczny podział sympatii politycznych: jesteśmy tym, czym nie są oni. Oni — faszyści, naziści, frankiści, nacjonaliści — są prawicą, my jesteśmy lewicą. Oni są wsteczni, my — postępowi. Oni oznaczają wojnę, my — pokój $^{6}$.

Równie obrazowo dychotomię tę ujął Frank Thompson, uczestnik wojny w Hiszpanii, oficer armii brytyjskiej zaangażowany w pomoc dla komunistycznej partyzantki w Bułgarii, gdzie został aresztowany i stracony w 1944 r.: ,Wolność i faszyzm nie mogą występować w tym samym świecie, a wolny człowiek, który uświadomi sobie tę prawdę, zawsze zwycięży"7.

Status oficjalnej doktryny historiozoficznej i polityczno-społecznej antyfaszyzmowi nadał Georgi Dymitrow, bułgarski komunista, przywódca Kominternu. Zgodnie z jego sformułowaniem z połowy lat 30. faszyzm to „otwarta terrorystyczna dyktatura najbardziej reakcyjnych, imperialistycznych i szowinistycznych elementów kapitału finansowego" reakcyjnych kręgów kapitału finansowego po to, aby doprowadzić do ucisku klasę robotniczą"9. Antyfaszyzm, któremu Dymitrow nadał jawnie antykapitalistyczny (a pośrednio również antydemokratyczny) charakter, stanowił zaś jedyną alternatywę na tak rozumiany faszyzm.

Ponieważ dyktatura [...] kręgów finansowego kapitału walczy z żywotnymi interesami całego społeczeństwa — jak napisano w jednym z enerdowskich słowników historycznych — istnieje konieczność i także możliwość pozyskiwania szerszych kręgów społecznych na rzecz ruchu antyfaszystowskiego wokół klasy robotniczej i jej partii ${ }^{10}$.

${ }^{5}$ Konieczność przeciwstawienia się wspólnemu wrogowi — faszyzmowi i faszystom — jednoczyła tak skrajnie różne i niezależne postaci jak André Malraux, Ignazio Silone, Simone Veil, Anna Seghers czy George Bernard Shaw. Osobom niezakorzenionym, poszukującym własnej tożsamości bądź odkrywającym ją na nowo — takim jak Arthur Koestler czy Walter Benjamin — antyfaszyzm przyniósł co najmniej prowizoryczne poczucie stabilności i przynależności do szerszej wspólnoty. Relacja przyjaciel-wróg, w której Carl Schmitt upatrywał podstawowe kryterium polityczności, z całą pewnością występowała więc w antyfaszyzmie. Sam Schmitt, jako zwolennik przeciwnego obozu, uznany był za wroga przez większość szanujących się antyfaszystów.

6 T. Judt, Postwar: A History of Europe Since 1945, New York 2005, s. 215-216 [thumaczenie własne tego i pozostałych fragmentów w języku angielskim].

7 Za P.J. Conradi, A Very English Hero: The Making of Frank Thompson, London 2012, s. 270.

8 Za A. Wolff-Powęska, Niemiecka Republika Demokratyczna wobec nazistowskiej przeszłości, „Przegląd Zachodni” 2011, nr 1, s. 53.

9 Za K. Wóycicki, Niemiecka pamięć. Rozrachunek z przeszłościa NRD i przemiany niemieckiej świadomości historycznej, Warszawa 2011, s. 77.

10 Ibidem, s. 77. 
Należy przy tym pamiętać, iż hasła jedności czy solidarności na lewicy nie zawsze uważane były za oczywistość i nie przez wszystkie strony. Przez niemal cały okres trwania Republiki Weimarskiej Ernst Thälmann, lider Komunistycznej Partii Niemiec (KPD), długo sprzeciwiał się sojuszowi z Niemiecką Partią Socjaldemokratyczną (SPD), skierowanemu przeciwko Narodowosocjalistycznej Niemieckiej Partii Robotników (NSDAP). To w socjaldemokratach, nie nazistach, upatrywał on najgroźniejszego przeciwnika w walce o głosy robotników i niższej klasy średniej. Określił ich mianem „socjalfaszystów”, w zgodzie z rezolucjami KPD z 1930 i 1931 r. oraz ustaleniami Kominternu z 1932 r. ${ }^{11}$ Mając poparcie Stalina, skutecznie eliminował osoby reprezentujące przeciwny pogląd, m.in. Karla Killboma. Krótko przed dojściem Hitlera do władzy owa skrajnie nieodpowiedzialna, bratobójcza polityka została zrewidowana (czego potwierdzeniem była teoria Dymitrowa i polityka tworzenia frontów ludowych). Było już jednak zbyt późno, aby odwrócić jej negatywne skutki. Thälmanna aresztowano w 1933 r., do 1944 r. przebywał w odosobnieniu, a w sierpniu tegoż roku skierowano go do obozu w Buchenwaldzie i wkrótce stracono na osobisty rozkaz Führera.

Już w czasie aresztowania, a zwłaszcza po śmierci, przedwojenny przywódca KPD został wywyższony do rangi symbolu. Mit Thälmanna, ,nieśmiertelnego syna Niemiec" (Deutschlands unterblicher Sohn), był silnie obecny w ideologii NRD ${ }^{12}$. Zastanawiające wydaje się, że „ojcowie założyciele” NRD, Walter Ulbricht i Wilhelm Pieck, jego bezpośredni następcy w kierownictwie KPD, na bazie której w 1946 r. utworzona została Socjalistyczna Partia Jedności Niemiec (SED), w publicznych wystąpieniach po zakończeniu wojny oraz licznych publikacjach, jakie szybko stawały się oficjalną wykładnią dziejów ${ }^{13}$, słowem nie

11 Zgodnie z treścią pierwszej rezolucji, uchwalonej 4 czerwca 1930 r., ,walka przeciw faszyzmowi jest nie do pomyślenia bez możliwie najostrzejszego sprzeciwu wobec Partii Socjaldemokratycznej i jej przywództwa - przywództwa, które stanowi decydujące narzędzie umożliwiające rozprzestrzenianie się faszyzmu w Niemczech". W rezolucji z listopada $1931 \mathrm{r}$. działacze KPD postanowili z kolei, iż: ,socjaldemokracja jest naszym głównym wrogiem wśród proletariatu. W obecnej fazie walki klasowej pragniemy zadać poważny cios socjaldemokracji”. Por. J. Herf, Divided Memory: The Nazi Past in the Two Germanies, Cambridge-London 1997, s. 14-15.

12 Jak wnioskuje Russel Lemmons, w micie tym sekularyzm łączył się z elementami religijnymi. Obok hagiograficznych biografii pióra Willego Bredela znajdziemy np. dwa filmy fabularne w reżyserii Kurta Maetziga (dobitnym świadectwem tego drugiego jest anioł czuwający w jego celi na jednym z rysunków). Można go zatem zaliczyć do wcale nielicznego grona komunistycznych „świeckich świętych”, obok takich postaci jak Che Guevara, Róża Luksemburg czy Marceli Nowotko. Jego imieniem uhonorowana została podsekcja organizacji młodzieżowej grupująca uczniów w wieku od 6 do 14 lat oraz liczne ulice, place i instytucje publiczne. Por. R. Lemmons, 'Germany's Eternal Son': The Genesis of Ernst Thälmann's Myth, 1930-1950, „German Studies Review” 32(2), May 2009, s. 343-356.

13 Zur Geshichte der Deutchen Arbeiterbewegung (1953) oraz Zur Geschichte der neusten Zeit (1955) Ulbrichta, jak również zbiory przemów i esejów Piecka z lat 1889-1950 były wielokrotnie wznawiane, ich łączny nakład liczył kilkaset tysięcy egzemplarzy. Por. J. Herf, Divided Memory..., s. 14. 
wspominają o politycznej krótkowzroczności Thälmanna ${ }^{14}$. W opinii Jeffreya Herfa to właśnie on ponosi co najmniej pośrednią odpowiedzialność za upadek mało stabilnej demokracji parlamentarnej z lat $1919-1933^{15}$. Brzemię odpowiedzialności zrzucono natomiast na barki SPD.

Przywołanie postaci Thälmanna wydaje się zasadne, gdyż postać ta i towarzysząca mu mitologizacja stanowią szczególnie spektakularny przykład czci okazywanej uczestnikom walki z faszyzmem. Poległych w tym nierównym boju upamiętniano jako męczenników. Do kategorii tej należał też Thälmann, choć - jak wspomniano już wcześniej — przeciwstawił się nazistom właściwie w ostatnim momencie, zaś po 1933 r. większość czasu spędził w areszcie.

Buchenwald, miejsce jego stracenia, gdzie znaczący odsetek wśród łącznej liczby ok. 250 tys. więźniów przebywających tam w latach 1937-1945 stanowili komuniści ${ }^{16}$, $\mathrm{z}$ obszaru martyrologii $\mathrm{w}$ niedługim tempie przeobraził się w „czerwony Olimp”. Podobny los spotkał Ravensbrück i Sachsenhausen, które po 1949 r. znalazły się w granicach NRD. Ze szczególnym pietyzmem pielęgnowano pamięć o wyzwoleniu pierwszego z obozów 11 kwietnia $1945 \mathrm{r}$. Gdy na wiadomość o zbliżaniu się oddziału generała George'a Pattona załoga SS rozpoczęła pośpieszną ewakuację, wyposażeni w broń palną oraz radiostację nadawczo-odbiorczą, członkowie obozowego ruchu oporu wykorzystali powstałe zamieszanie i po kilkugodzinnej walce (przy śladowym oporze ze strony Niemców) opanowali kilka wież strażniczych tuż przed przybyciem tam Amerykanów ${ }^{17}$.

Jak zauważa Siobhan Kattago, wraz z pogłębianiem się zimnej wojny „historyczny kontekst zbliżających się wojsk amerykańskich i wyzwolenia był wypierany na rzecz mitologizowania buntu więźniów jako samowyzwolenia się

14 Przyszli liderzy NRD, jeszcze przed objęciem władzy we Wschodnich Niemczech, kilkukrotnie wyrazili samokrytykę z powodu błędnej polityki prowadzonej w pierwszej połowie lat 30. Podczas kolejnego zebrania Kominternu w sierpniu 1935 r. Pieck odważył się przyznać, że działacze KPD zlekceważyli zasadnicze źródło niebezpieczeństwa, którym był „hitleryzm”. W podobnym tonie wypowiadał się Ulbricht, przyznając, iż KPD „główne uderzenie skierowała w stronę socjaldemokracji, podczas gdy powinien to być faszyzm". Por. ibidem, s. 17-18.

15 Por. ibidem, s. 13.

16 „Do 1943 r. w Buchenwaldzie przebywało 17000 więźniów, w większości komuniści niemieccy, socjaldemokraci, kryminaliści i osoby duchowne. Komuniści i socjaldemokraci współpracowali ze sobą przy tworzeniu Międzynarodowego Komitetu Obozowego, zajmującego się zbieraniem broni na poczet przyszłego powstania i organizowaniem akcji sabotażowych w pobliskich fabrykach amunicji. Żydzi nie stanowili znaczącej społeczności w obozie, gdyż w tamtym okresie transportowano ich bezpośrednio do obozów śmierci na Wschodzie niż do niemieckich obozów pracy. Pod koniec 1943 r. dotarł tam transport z francuskimi więźniami razem z 8000 radzieckich jeńców wojennych, których niemal natychmiast zgładzono. W 1944 r., wraz z ewakuacją obozów śmierci na Wschodzie, żydowscy więźniowie zapełnili Buchenwald [wśród nich był m.in. Elie Wiesel wraz z ojcem, który nie dożył wyzwolenia - S.P.], zostali jednak oddzieleni od reszty w tzw. "małym obozie« i nie byli chronieni przez Międzynarodowy Komitet Obozowy [...] od 1937 r. [data założenia obozu - S.P.] do 1945 r. w Buchenwaldzie zginęło ok. 51000 osób" (por. S. Kattago, Ambigious Memory: The Nazi Past and German National Identity, Westport 2001, s. 90-91).

17 Por. ibidem, s. 91. 
z faszyzmu" ${ }^{18}$. Narrację tę uwiecznił pomnik autorstwa Fritza Cremera z 1958 r. ukazujący jedenastu więźniów (dziesięciu dorosłych i dziecko) „wyczerpanych, lecz zwycięskich" 19 .

W sytuacji, gdy przestrzeń symboliczną wypełniali herosi bez skazy ${ }^{20}$ lub fałszywe, choć zrozumiałe od strony psychospołecznej, wyobrażenie o powszechnym akcesie do ruchu oporu (specyfika europejskiego powojnia ${ }^{21}$ ), z pola widzenia znikała „szara strefa” egzystowania w warunkach wojny/okupacji, by nawiązać do osławionej frazy Primo Leviego ${ }^{22}$, na którą składały się m.in. ko-

18 Ibidem, s. 92.

19 Ośmiu z nich (wliczając dziecko) tworzy zwartą formację. Szczególna ekspresja cechuje postaci znajdujące się pośrodku: więzień usytuowany w centralnym planie pada niby w agonii, kontrastuje $\mathrm{z}$ tym postawa sąsiada $\mathrm{z}$ lewej strony unoszącego rękę $\mathrm{z}$ dwoma palcami w geście victorii, zauważalne są dwa atrybuty bojowe — karabin i szturmówka. Uwagę przykuwa też dwójka więźniów z prawej strony. $Z$ dystansu przyglądają się pozostałym osobom i, pomimo zachęty wyrażonej w ekspresyjnej gestykulacji jednego z jej członków zwróconego w ich stronę, ich zdystansowanie i mimika twarzy zdają się sugerować, że raczej nie przyłączą się do grupy. Niewykluczone, iż tworząc te postaci, autor miał na myśli Żydów. Proporcje wyrażone w tym pomniku (dziecko/ośmiu bojowników/dwoje gapiów) odzwierciedlały oficjalnie obowiązujący pogląd o masowym charakterze oporu przeciw faszyzmowi obejmującym, poza nielicznymi wyjątkami, niemal całe społeczeństwo. Por. też m.in. A. Moaz, RePlacing Memory: The Reorientation of Buchenwald, „Cultural Geographies” 10, 2003, nr 1, s. 5-6; J. Herf, Divided Memory..., s. 175-181; S. Kattago, op. cit., s. 89-96; J.B. Olsen, Tailoring Truth: Politicizing the Past and Negoriating Memory in East Germany, 1945-1990, New York-Oxford 2015, s. 54-70; A. Wolff-Powęska, Niemiecka Republika Demokratyczna wobec nazistowskiej przeszłości..., s. 64-66.

${ }^{20} \mathrm{~W}$ relacjach z Buchenwaldu, publikowanych w oficjalnym obiegu, komunistów zachwalano jako wzorowych współtowarzyszy, nieobojętnych na krzywdę innych, w tym niekomunistycznych więźniów (Żydów, chrześcijan, socjaldemokratów czy świadków Jehowy). Zeznania świadków w procesach byłych członków załogi obozu, których szeroka fala zatoczyła się w Niemczech Zachodnich od wczesnych lat 60 ., oraz późniejsze badania historyków podważyły ów romantyczny obraz. Jak się okazało, nadreprezentatywna liczba komunistów wypełniała tam rolę więźniów funkcyjnych. Za cenę kolaboracji z SS uzyskiwali dodatkową żywność, którą niechętnie dzielili się z osobami niebędącymi komunistami, i przywileje znacząco zwiększające ich szansę na przeżycie. Tzw. „czerwoni kapo” (rote Kapos) różnili się zatem od bojowników z monumentu Cremera. Por. ibidem, s. 95-96; Z. Wóycicka, Przerwana żałoba. Polskie spory wokót pamięci nazistowskich obozów koncentracyjnych i zagłady, 1944-1950, Warszawa 2009, s. 91-92 i 185-186.

21 Jak pisze Tony Judt: ,aby zostać uznanym za pozbawiony winy, dany naród musiał stawić opór - i to w swej zdecydowanej większości - argument ten ustalony został odgórnie i pedantycznie egzekwowany w całej Europie, od Włoszech przez Polskę, od Holandii do Rumunii. Wszędzie tam, gdzie historyczne dane świadczyły przeciw zniekształceniom - we Francji i Włoszech, gdzie antyfaszystowska partyzantka pojawiła się późno i ograniczała się do północnych obszarów, na Niderlandach z rażąco wyolbrzymioną liczbą heroicznych wieśniaków ocalających zestrzelonych brytyjskich lotników, którzy stali się częścią powojennej mitologii — od pierwszych miesięcy po wojnie uwagę świadomie zwracano na przykłady i historie nieustająco powtarzane i przejaskrawiane w powieściach, popularnych podaniach, radiu, gazetach, a w szczególności w kinie". Por. T. Judt, The Past is Another Country: Myth and Memory in Postwar Europe, „Deadalus” 121, Fall 1992, nr 4 (Immobile Democracy), s. 89-90.

22 Por. P. Levi, The Drowned and Saved, [w:] The Complete Works of Primo Levi, red. A. Goldstein, t. III, New York 2015, s. 1366, 2590-2620. 
laboracja, oportunizm, indyferentyzm, wrogość względem zbrojnego podziemia wśród ludności cywilnej, wynikająca z obawy przed akcjami odwetowymi ${ }^{23}$, konieczność kompromisów (społeczność czy jednostka, ocalenie najbliższych krewnych czy szerszej grupy osób), tragiczność stawania przed decyzjami, z których każda rodziła równie negatywne skutki (tzw. choiceless choices ${ }^{24}$ ) czy inne przejawy ambiwalentnych zachowań. Mając za sobą przeżycia związane z konspiracją, prześladowaniami ze strony nazistów (których notabene stali się pierwszą zbiorową ofiarą), pobytem w obozach koncentracyjnych, przymusową emigracją pod kuratelą ZSRR, komuniści niemieccy mieli pełne prawo odczuwać moralną wyższość względem swoich rodaków w kraju. W większości nie odpowiedzieli oni bowiem na ponawiane wezwania o konieczności wyzwolenia ojczyzny z rąk faszystów, zanim zrobią to alianci. Co gorsza, z zaciekłością bronili upadającego reżimu w ostatnich godzinach jego trwania ${ }^{25}$. Odezwa KPD z 13 czerwca 1945 r. zawierała następujące zdania:

Nie tylko Hitler winny jest zbrodni przeciwko ludzkości! 10 milionów Niemców, którzy zagłosowali na niego w wolnych wyborach, choć komuniści ostrzegali: „kto głosuje na Hitlera, ten głosuje na wojnę", również ponosi część odpowiedzialności [...]. Naszym nieszczęściem jest to, że miliony, miliony Niemców uległo nazistowskiej demagogii i że trucizna bestialskiej doktryny rasistowskiej oraz „walka o przestrzeń życiową” były w stanie zainfekować organizmy ludzi ${ }^{26}$.

Aby uzyskać legitymizację za strony społeczeństwa, uznanego przez nich za tradycyjnie antykomunistyczne, przywódcy SED zdecydowali się na radykalne posunięcie - swoje doświadczenie rozszerzyli na resztę mieszkańców obszaru między Odrą a Łabą. Anna Wolff-Powęska wnioskuje, iż manewr ten był „największym fałszerstwem i jednocześnie najdonioślejszym mitem założycielskim wschodnioniemieckiego państwa"27. Jak zauważa z kolei Kazimierz Wóycicki, antyfaszyzm rozumiany jako „część indywidualnych biografii” po niewątpliwej

23 To cywile, a nie partyzanci, byli głównymi ofiarami działalności partyzantów i pozostałych przedstawicieli zbrojnego podziemia. Skrajnym przejawem tej niechęci było wydawanie pierwszych przez drugich w ręce wroga/okupanta.

24 Twórcą tego pojęcia jest amerykański literaturoznawca Lawrence Langer. Por. m.in. L. Langer, Ghetto Chronicles: Life at the Brink, [w:] L. Langer, Admitting the Holocaust: Collected Essays, New York-Oxford 1995, s. 45-50 i 80; L. Langer, Versions of Survival: The Holocaust and the Human Spirit, New York 1982, s. 72; L. Langer, The Dilemma of Choice in the Deathcamps, [w:] Holocaust: Religious and Philosophical Implications, red. J.K. Roth, M. Berenbaum, Saint Paul 1989, s. 222-232.

25 Z łączną liczbą 1298745 poległych bitwa o Berlin (16.04.-2.05.1945) była drugą najkrwawszą potyczką II wojny światowej, ustępuje jedynie Stalingradowi (między 1250000 a 1798619 poległych). Por. 10 Bloodiest Battles of World War II, http://www.militaryeducation.org/10-bloodiest-battles-of-world-war-ii/ (dostęp: 30.06.2016).

26 J. Herf, Divided Memory..., s. 29-30.

27 A. Wolff-Powęska, Niemiecka Republika Demokratyczna wobec nazistowskiej przeszłości..., s. 55. 
Zivilisationsbruch (,katastrofie cywilizacyjnej”28), jaką stanowił koniec III Rzeszy, stał się ,ideologią dla szeregowych, zwykłych Niemców”29. W dość mglistej definicji faszyzmu jako zdegenerowanej, skrajnie reakcyjnej dyktatury łączącej cechy kapitalizmu i imperializmu, sformułowanej przez Georgiego Dymitrowa, lata 1933-1945 wpisane zostały w szerszy kontekst kilkusetletniej rywalizacji klas i akumulacji kapitału. Historyczna rzeczywistość III Rzeszy uległa w ten sposób rozmyciu, a pośrednio wraz z nią współudział „zwykłych” Niemców w wydarzeniach minionych 200 lat.

Tak rozumiany „faszyzm” zastąpił „,narodowy socjalizm” — jednym z najpoważniejszych zarzutów stawianych Hitlerowi było to, iż ,śmiał [on - S.P.] [...] użyć słów »narodowy « i »socjalistyczny« — słów, z którymi prawdziwi ludzie wiążą tak szlachetne uczucia" ${ }^{30}$. Manipulacje na faktach i sposobie ich interpretacji, dokonywane z mniejszą bądź większą finezją przez cztery dekady NRD, S. Kattago wiąże z procesem „uniwersalizacji przeszłości”, który towarzyszył formowaniu się ,antyfaszystowskiej tożsamości społecznej” ${ }^{1}$. Antyfaszyzm nie ograniczał się jednak wyłącznie do przeszłości. Wręcz przeciwnie, ściśle wiązał się z postępem. Zgodnie z popularną wśród teoretyków marksizmu-leninizmu eschatologiczną wizją dziejów (jednym z jej wyznawców był Wilhelm Pieck ${ }^{32}$ ), socjalizm à la NRD powstał w rezultacie kryzysu kapitalizmu, czego ekstremalnym przejawem był faszyzm III Rzeszy. Industrializację na wzór ZSRR, kolektywizację rolnictwa, uspołecznienie środków produkcji i wiele reform od $1945 \mathrm{r}$. uzasadniono potrzebą umacniania fundamentów nowego, ,antyfaszystowskiego państwa" ${ }^{33}$. Gdy okazało się, iż pamięć o bohaterach walki z faszyzmem to niewystarczające źródło jego legitymizacji - na co pewien wpływ miało stopniowe odchodzenie świadków oraz przejmowanie sterów władzy przez „pokolenie '29”' „drugą generację Hitlerjugend”34 (osoby, które uzyskały pełnoletniość już po zakończeniu wojny i których jedyną wojenną kartą w najczęstszym przypadku był udział $\mathrm{w}$ jednostkach obrony przeciwlotniczej) — podjęto nieskuteczne próby

28 K. Bachmann, Dlugi cień Trzeciej Rzeszy. Jak Niemcy zmieniali swój charakter narodowy, Wrocław 2005, s. 116. Sformułowanie to zaczerpnięte zostało od Dana Dinera, por. D. Diner, Vorwort des Herausgebers, [w:] Zivilisationsbruch: Denken nach Auschwitz, red. D. Diner, Frankfurt am Main 1988, s. 7-13.

${ }^{29}$ K. Wóycicki, op. cit, s. 80.

30 Przemówienie prokuratora Władysława Bednarza podczas procesu szefa zarządu getta łódzkiego Hansa Biebowa przed Sądem Okręgowym w Łodzi w 1947 r. Por. ŻIH, 344: Procesy przestępców wojennych, S. 1/599: 5-y dzień procesu przeciwko Biebowowi, k. 9.

31 Por. S. Kattago, op. cit., s. 80-81.

32 Por. J. Herf, Divided Memory..., s. 15.

33 Por. D. Diner, On the Ideology of Antifascism, „New German Critique”, January 1996, z. 67, s. 127.

34 Por. M. Fulbrook, Demography, Opportunity or Ideological Conversion? Reflections on the Role of the 'Second Hitler YouthGenerations', or '1929ers' in the GDR, [w:] Popular Opinion in Totalitarian Regimes, red. P. Corner, Oxford-New York 2009, s. 184-207. 
powiązania NRD z dawną historią Niemiec (rewolty chłopskie, reformacja, antynapoleońskie wojny wyzwoleńcze).

Od lat 80. (choć przesłanki ku temu pojawiły się już wcześniej) nastąpił więc etap konstruowania „,niemieckiej antyfaszystowskiej tożsamości społecznej”35. Nie trwał on długo. Państwowe uroczystości z okazji 400-lecia urodzin Thomasa Müntzera w 1989 r. okazały się preludium końca NRD.

\section{$* * *$}

Być antyfaszystą po zakończeniu II wojny światowej oznaczało znaleźć się wśród „Zwycięzców historii” (Siegers der Geschichte) ${ }^{36}$. Jak jednak wspomniano na początku, antyfaszyzm po $1945 \mathrm{r}$. różnił się od tego z międzywojnia. Lata 1918-1939 charakteryzowały wojna w Hiszpanii z udziałem Międzynarodowych Brygad, fronty ludowe, poprzedzone wewnętrzną rywalizacją na lewicy, protesty uliczne, manifesty intelektualistów. ZSRR - jako jedyne państwo, w którym zapanował socjalizm - stanowił punkt odniesienia dla antyfaszystów w Hiszpanii czy we Francji. Władze radzieckie patronowały ich działalności, trudno jednak mówić o pełnej kontroli.

Koniec wojny przyniósł reorientację dotychczasowego porządku. Bezdyskusyjnej kompromitacji faszyzmu towarzyszył podwójny tryumf ze strony ZSRR — w wymiarze rzeczywistym, tj. polityczno-militarnym, i wizerunkowym. Dan Diner pisze w tym kontekście o „powojennej gratyfikacji” (Nachkriegsbonus) ${ }^{37}$.

Maj 1945 r. stał się kolejną symboliczną datą, obok października 1917 r. Sugestywna siła obrazów ukazujących wieszanie czerwonej flagi na Bramie Brandenburskiej wydawała się jeszcze mocniejsza niż przejęcie Pałacu Zimowego w Petersburgu czy wystrzał z Aurory. Ponadto cementowały one romantyczny mit zwycięskiej Armii Czerwonej, w który bardzo wielu chciało wierzyćc ${ }^{38}$. Wiążący

35 S. Kattago, op. cit., s. 96-110; A. Wolff-Powęska, Niemiecka Republika Demokratyczna wobec nazistowskiej przeszłości..., s. 67-69; H. Münkler, Mity Niemców, Warszawa 2013, s. 347-384.

36 Por. S. Kattago, op. cit., s. 85; A. Wolff-Powęska, Niemiecka Republika Demokratyczna wobec nazistowskiej przeszłości..., s. 58; A. Wolff-Powęska, Pamięć - brzemię i uwolnienie. Niemcy wobec nazistowskiej przeszłości (1945-2010), Poznań 2011, s. 219-322.

37 D. Diner, op. cit., s. 125.

38 Właśnie z tego powodu warta przytoczenia wydaje się relacja Wasilija Grossmana, radzieckiego pisarza pochodzenia żydowskiego, który jako korespondent wojenny gazety „Krasnaja Zwiezda" przebył pełny szlak bojowy Armii Czerwonej, od oblężenia Moskwy po zdobycie Berlina, do którego to wydarzenia odnosi się następujący jej fragment: „Cudzoziemcy [wywiezieni na roboty do Niemiec i jeńcy wojenni]. Ich cierpienia, ich droga, pieśni, krzyki i pogróżki pod adresem niemieckich żołnierzy. Cylindry, bokobrody. Młody Francuz powiedział mi: »Monsieur, kocham waszą armię i dlatego przykro mi patrzeć na jej postępowanie z dziewczętami i kobietami. To będzie bardzo szkodliwe dla waszej propagandy «" (por. W.S. Grossman, Pisarz na wojnie: Wassilij Grossman na szlaku bojowym Armii Czerwonej 1941-1945, oprac. A. Beevor, L. Winogradowa, przeł. M. Antosiewicz, Warszawa 2006, s. 352-353). 
wpływ narracji antyfaszystowskiej nie ograniczał się już wyłącznie do komunistycznych aparatczyków bądź poputczików ${ }^{39}$ na Zachodzie. Zyskała ona obligatoryjny status w państwach należących do radzieckiej strefy wpływów — szczególnie w NRD, która oparła na niej swój byt, przynajmniej od samego początku swego funkcjonowania. Jak konkluduje Kazimierz Wóycicki:

[...] stwierdzenie ,jestem antyfaszystą", ,jestem już po dobrej stronie” mogło znaczyć dla wielu ,jestem już po dobrej stronie”. Antyfaszyzm był sowiecką formułą propagandową, która jednak w szczególnych powojennych warunkach nałożyła się na pragnienie czy nadzieję wielu Niemców uporania się z ciężarem klęski i rozpoczęciem nowego życia ${ }^{40}$.

Upadek „tysiącletniej” III Rzeszy, 12 lat od momentu jej powstania, jedynie utwierdził W. Piecka co do słuszności swego przekonania, by katastrofy postrzegać jako wstęp do rewolucji. Dla niego i pozostałych „Moskwian”41 przewodnia rola ZSRR jako państwa narzucającego wypracowane przez nie wcześniej rozwiązania instytucjonalne i/lub ideologiczne nie budziła wątpliwości. Treść odezwy z 13 czerwca 1945 r. sugerowała też, że nie mieli oni złudzeń co do rzeczywistej postawy lwiej części mieszkańców radzieckiej strefy okupacyjnej, późniejszych obywateli NRD. Z tego powodu odrzucona została koncepcja powrotu do demokracji na wzór Weimaru ${ }^{42}$. Po kilkudziesięciu miesiącach zwodzenia społeczeństwa, zachodniej opinii publicznej i własnych sojuszników we froncie ludowym poprzez tzw. Scheindemokratie („,demokrację pozorowaną") — gdy rozbieżności między niedawnymi aliantami okazały się nierozstrzygalne, zaś perspektywę zjednoczenia Niemiec $\mathrm{w}$ duchu socjalizmu przekreślił pierwszy kryzys berliński (1948) - SBZ/NRD coraz wyraźniej przybierały postać specyficznej dyktatury, w której przymus łączył się z perswazją. Oba te elementy były obecne $\mathrm{w}$ denazyfikacji oraz procesach sądowych przeprowadzanych najpierw w strefie radzieckiej, a następnie w NRD. Przybrały one intensywniejszy, bardziej

39 Termin wymyślony przez Lwa Trockiego. Posługiwano się nim w przypadku rosyjskich pisarzy, którzy sympatyzowali z bolszewikami, lecz nie przyłączyli się do nich. Później rozszerzono jego znaczenie również na ich zagranicznych zwolenników. Najbliższy znaczeniowo odpowiednik w języku angielskim: fellow traveler. Por. R. Pipes, Rosja bolszewików, przeł. T. Szafar, Warszawa 2007, s. 221.

40 K. Wóycicki, op. cit., s. 80.

${ }^{41}$ Moskwa zapewniła schronienie przyszłej kadrze przywódczej NRD — jej symbolem stał się Hotel Lux na ulicy Gorkiego (obecna Twierskaja) w ścisłym centrum miasta. Podobnie jak inni reprezentanci Kominternu, również oni nie uniknęli wewnętrznych czystek w latach 30., które przetrwały jedynie osoby bezgraniczne lojalne Stalinowi, w tym Ulbricht i Pieck. Po zakończeniu wojny stanęli do rywalizacji o władzę (w ostateczności zwycięskiej) z komunistami, którzy okres 1933-1945 spędzili w ojczyźnie. Doświadczenia prześladowania ze strony nazistów oraz czystek zasadniczo wpłynęły na ich światopogląd stanowiący specyficzny amalgamat „lęku, oportunizmu, potrzeby obrony siebie, denuncjacji i cynicznego pragmatyzmu", jak stwierdza Jürgen Danyel. Por. A. Wolff-Powęska, Niemiecka Republika Demokratyczna wobec nazistowskiej przeszłości..., s. 54; K. Wóycicki, op. cit., s. 79-80; W. Leonhard, Dzieci Wolności, Warszawa 2013.

42 J. Herf, Divided Memory..., s. 30-31. 
zdecydowany charakter niż w pozostałych strefach okupacyjnych. Jak podaje J. Herf, w latach 1945-1949 ok. 12,5 tys. osób było sądzonych za zbrodnie wojenne popełnione w czasie trwania III Rzeszy ${ }^{43}$ : od 200 do 300 z nich zostało skazanych na karę śmierci, którą w blisko 100 przypadkach wykonano. W samym $1945 \mathrm{r}$. 390-478 byłych członków NSDAP straciło pracę. Do kwietnia 1947 r. 262 komisji składających się w większości z członków bądź sympatyków KPD/SED przeegzaminowało 850 tys. byłych funkcjonariuszy nazistowskich, 65 tys. z nich otrzymało różny wymiar kar. Do kwietnia roku następnego pracy pozbawiona została przybliżona liczba 520 tys. osób, co stanowiło 2,7\% ogółu społeczeństwa ${ }^{44}$. $\mathrm{Z}$ drugiej strony, wraz z decyzją Radzieckiej Administracji Wojskowej w Niemczech (SMAD) nr 35 z 26 lutego 1948 r. o rozwiązaniu komisji denazyfikacyjnej, rozrachunek z III Rzeszą uznano za oficjalnie zakończony. W ten oto sposób proces, który w Niemczech Zachodnich ciągnął się przez dziesięciolecia i zyskiwał na intensywności im dalej od zakończenia wojny — zwłaszcza w latach 60. i 70., gdy toczyły się dwa wielkie postępowania sądowe we Frankfurcie nad Menem (1963-1965) i Düsseldorfie (1975-1981); pierwsze tyczyło się Auschwitz, drugie Majdanka - na Wschodzie został on ,przepracowany” w ciągu zaledwie kilku powojennych lat.

Równolegle $\mathrm{z}$ denazyfikacją toczyły się działania zmierzające do możliwie jak najszerszej integracji społeczeństwa wokół nowo powstałego państwa. Przedstawiając siebie jako demokratów, pozorując liberalizację, politycy KPN/NRD ubiegali o sympatię ze strony postępowych, liberalno-lewicowych elit i kręgów opiniotwórczych. Odpowiadając z kolei na zarzut Piecka o tym, że komuniści niemieccy $\mathrm{w}$ niewystarczającym stopniu odwoływali się do sentymentów narodowych — była to jedna $\mathrm{z}$ głównych przyczyn ich porażki z NSDAP 45 - zwrócili się również ku konserwatystom, którzy w przeszłości zagłosowali na partię Hitlera. Wolfgang Leonhard, który okres dzieciństwa i wczesnej młodości spędził w ZSRR, a od lipca 1943 r. zaangażował się w działalność Komitetu Narodowego Wolne Niemcy (NKFD), w autobiografii przywołuje swoje wielkie zdumienie, gdy na czołówce „Freies Deutschland”, gazety podporządkowanej tej organizacji, zauważył czarno-biało-czerwone paski — nawiązanie do flagi Związku Północnoniemieckiego, barwy narodowe Rzeszy Niemieckiej w latach 1933-1945. Przytacza też wyjaśnienie udzielone mu przez Hansa Mahlego, wpływowego członka NKFD, wiernie odzwierciedlające strategiczną koncyliacyjność powojennego antyfaszyzmu:

„Freies Deutschland” nie jest zwykłą kontynuacją ruchu antyfaszystowskiego, stawia sobie natomiast za cel $[\ldots]$ zjednoczenie wszystkich sił politycznych, w tym także narodowców,

${ }^{43}$ Por. J. Herf, Politics and Memory in West and East Germany since 1961 and in United Germany since 1990, [w:] After Eichmann: Collective Memory and the Holocaust since 1961, red. D. Cesarani, London-New York 2005, s. 42.

44 J. Herf, Divided Memory..., s. 72.

45 Ibidem, s. 16 i 18-19. 
konserwatystów, a nawet nazistów, przynajmniej tych, którzy w pewnym sensie są w opozycji wobec Hitlera [...] Początkowo dla ruchu „Freies Deutschland”przewidziano flagę czarno-czerwono złotą [oficjalne barwy narodowe Niemiec w latach 1919-1933 i ponownie od 1989 r. - S.P.] [...] Ale sowieccy towarzysze mieli wątpliwości [...] Czarno-czerwono-złota flaga przypomina okres Republiki Weimarskiej, kojarzy się ze słabością, kryzysem i masowym bezrobociem, a to mogłoby ograniczać nasze wpływy. Flaga czarno-biało-czerwona jest natomiast lepsza, bo bardziej popularna wśród oficerów Wehrmachtu, dzięki czemu możemy liczyć na szeroką bazę ${ }^{46}$.

Nawiązując do często powracającego w filmach państwowej wytwórni DEFA (Deutsche Film, AG) motywu nawrócenia i odkupienia błędów (Wiedergutmachtung) ${ }^{47}$, władze NRD wyciągnęły rękę do wcale nielicznej części społeczeństwa uwikłanej w działalność na rzecz minionego reżimu - jako propagandystów, biurokratów, wojskowych czy zwykłych fellow travellers, korzystających z antysemickiego ustawodawstwa lub polityki ekspansji terytorialnej - w zamian oczekując całkowitej lojalności. W maju 1948 r. utworzono koncesjonowaną przez władze NRD Narodowo-Demokratyczną Partię Niemiec (NDPD). „Powołano ją celowo dla rzekomo wyedukowanych na nowo członków NSDAP” - pisze K. Wóycicki. — „Był to również azyl dla wielu byłych oficerów Wehrmachtu”48. Swych podwojów przed nimi nie zamknęła też całkowicie przewodnia SED: nawet po czystce będącej rezultatem wewnętrznych starć między „Moskwianami”, rodzimymi komunistami a osobami uznanymi za „kosmopolitów”, które okres 19331945 spędziły poza Niemcami i ZSRR, udział byłych nazistów oscylował wokół $8 \% 49$. W listopadzie $1949 \mathrm{r}$. Izba Ludowa NRD uchwaliła ustawę uchylającą kary dla byłych członków i zwolenników NSDAP i oficerów Wehrmachtu. W 1952 r. natomiast jednogłośnie przegłosowano ustawę o prawach obywatelskich dla byłych oficerów faszystowskiego Wehrmachtu oraz byłych członków i zwolenników NSDAP $^{50}$. Praktyka ta motywowana była koniecznością zapewnienia młodemu państwu takiej ilości odpowiednio wykwalifikowanych elit funkcyjnych — techników, urzędników, administratorów, oficerów, edukatorów, ludzi pióra itd. — aby umożliwić jego sprawne funkcjonowanie, zanim osoby mające „brunatny epizod”

46 W. Leonhard, op. cit., s. 207.

47 Motyw ten był szczególnie obecny w tzw. Gegenwartsfilme, tj. produkcjach, gdzie twórcy zabierali głos na współczesne tematy, zazwyczaj odnosząc się do najbardziej palących kwestii społecznych (niedociągnięcia NRD, degrengolada młodzieży, konflikty międzygeneracyjne, powojenny nihilizm itp.). Przykładowo w filmie Berlin: Ecke Schönhausern (1957) to młody mężczyzna, który po krótkotrwałym i zgubnym w skutkach zafascynowaniu konsumpcyjną, quasi-kryminalną rzeczywistością Berlina Zachodniego odnajduje równowagę jako prawomyślny obywatel NRD, członek Volkspolizei. Por. S. Heiduschke, East German Cinema: DEFA and Film History, New York-London 2013, s. 61-67.

48 K. Wóycicki, op. cit., s. 84-85.

49 Ibidem, s. 84.

50 A. Wolff-Powęska, Niemiecka Republika Demokratyczna wobec nazistowskiej przeszłości..., s. 56. 
zostaną zastąpione przez nowe kadry, uformowane już przez NRD. Dietman Remy i Axel Salheiser słusznie formułują więc tezę o reintegracji lub ciągłości elit ${ }^{51}$.

Biorąc pod uwagę dzisiejszy stan wiedzy o tym, jak liczny był udział dawnych zwolenników III Rzeszy w SED i instytucjach NRD ${ }^{52}$, jako przejaw szczególnej hipokryzji jawi się nagłaśnianie licznych skandali w związku z nazistowską przeszłością zachodnioniemieckich polityków - by wspomnieć choćby Hansa Globkego, prawnika, jednego z najbliższych współpracowników Konrada Adenauera, szefa biura, a następnie sekretarza stanu w Federalnym Urzędzie Kanclerskim. O tym, że był on współautorem wiążącego komentarza do ustaw norymberskich w 1935 r. oraz projektów licznych rozporządzeń, które realizować miał oddział IVB4 RSHA, odpowiedzialny za realizację tzw. ostatecznego rozwiązania kwestii żydowskiej, media dowiedziały się z ust Adolfa Eichmanna na jego procesie w Jerozolimie w 1961 r. Korzystając z usług ludzi takich jak Globke, RFN i NRD kierowały się takimi samymi, pragmatycznymi motywacjami. To, że drugim z tych państw nigdy nie zachwiały kryzysy rządowe, takie jak ten z 1961 r., wynikało z autorytarnego stylu jego zarządzania: władze NRD pilnowały, aby byli naziści nie dochodzili do wyższych stanowisk; skutecznym narzędziem samodyscypliny, a w skrajnych przypadkach — szantażu, było rozeznanie ich przełożonych w tym, „co robili przed 1945 r."53 Powtarzające się z regularną częstotliwością sensacyjne doniesienia o niechlubnej przeszłości danego ministra, wysokiego urzędnika czy burmistrza landu - w drugiej połowie lat 60. dosięgły one najwyższego stanowiska w państwie, po tym jak kanclerz w rządzie ,wielkiej koalicji” CDU/SPD (1966-1969), Kurt Georg Kiesinger, został oskarżony o zatajenie swej służby jako naczelnika propagandy MSZ w latach 1940-1945 ${ }^{54}$ — dla propagandystów [sic] NRD stanowiły oręż w ideologicznej rywalizacji z Republiką Federalną Niemiec (RFN).

W 1957 r. utworzono specjalną jednostkę, Komitet Zjednoczenia Niemiec (ADE), której kierownikiem w latach 1957-1963 był Albert Norden, członek Komitetu Centralnego SED, sekretarz ds. agitacji i propagandy. Wbrew oficjalnej

51 Por. D. Remy, A. Salheiser, Integration or Exclusion: Former National Socialists in the GDR, „Historical Social Research” 35, 2010, nr 3(133), s. 10.

$52 \mathrm{~W}$ wielu miejscowościach przekraczał 10\% łącznej liczby członków partii (legitymacja partyjna była warunkiem pełnienia funkcji publicznych), zaś w Erfurcie w 1954 r. osiągnął on $35,8 \%$. Według obecnych danych w samym 1951 r. wśród 5833 funkcjonariuszy, zatrudnionych w różnych ministerstwach NRD, 940 osób stanowili byli członkowie NSDAP. Por. K. Wóycicki, op. cit., s. 84.

53 D. Remy, A. Salheiser, op. cit., s. 10.

54 W 1968 r., na dorocznym zjeździe CDU, Kiesinger został publicznie spoliczkowany przez Beate Klarsfeld — zaangażowaną wraz z mężem (Serge'em Klarsfeldem) w upamiętnienie zbrodni ludobójstwa Żydów i działania zmierzające do postawienia przed sądem osób za nie odpowiedzialnych. Klarsfeld zrywająca się z trybuny dla publiczności i wymierzająca cios w policzek z okrzykiem „nazisto, podaj się do dymisji!” (Nazi, tritt zurück!) to jeden z najbardziej ikonicznych obrazów w najnowszej historii Niemiec. Por. G. Walters, Ścigając zło, przeł. T. Łuczak, Warszawa 2011, s. 352. 
nazwie, będącej nawiązaniem do rozwiązanego po wojnie NKFD, rzeczywistym zadaniem komitetu było przeprowadzenie zmasowanej kampanii oczerniającej zachodnich sąsiadów, co znalazło potwierdzenie chociażby w tytułach wydawanych przez nią komunikatów (np. Oskarżamy: Ośmiuset splamionych krwiq sędziów podpora rezimu Adenauera z 1959 r.) czy obszerniejszych publikacji (np. Brazowa księga: nazistowscy przestępcy wojenni w Republice Federalnej - państwo, ekonomia, armia, administracja, sprawiedliwość, szkolnictwo z 1965 r., zawierająca listę 1900 podejrzanych $)^{55}$. Pod nadzorem ADE odbywały się także pokazowe procesy sądowe. W rezultacie jednego z nich Globkego zaocznie uznano winnym popełniania zbrodni przeciw ludzkości i skazano na karę dożywocia ${ }^{56}$. Przedstawiciel Komitetu, prawnik i znany publicysta Friedrich Karl Kaul, udał się na proces Eichmanna w charakterze oficjalnego obserwatora ze strony NRD. W swoich wypowiedziach często wskazywał na bliskie związki łączące RFN z III Rzeszą. Poprzez pozwy cywilne skierowane przeciw Eichmannowi próbował też wpłynąć na przebieg postępowania. Ostatecznie sędziowie izraelscy odrzucili jego wniosek.

W opinii J. Herfa działania te miały na celu odwrócenie uwagi od wydarzeń mających miejsce w NRD (walki frakcyjne w SED, kampania antyżydowska z zimy 1952/1953, sthumienie protestów robotników w Berlinie Wschodnim 17 czerwca 1953 r.) i strukturalnych problemów (masowa migracja do RFN w latach 50. sięgająca liczby 200 tys. osób rocznie, załamanie gospodarcze, niski prestiż międzynarodowy) ${ }^{57}$. Niemniej ich konsekwentna realizacja, a chwilami błyskotliwość, spowodowały, iż fałszywa w swojej istocie teza o antyfaszystowskich Niemczech Wschodnich i RFN jako pogrobowcu III Rzeszy, jak również o radykalnych rozliczeniach z przeszłością dokonanych w NRD i właściwym ich braku na zachód od Łaby, zyskały wielu zwolenników. „[...] kiedy słucha się Kaula, kiedy się mówi z dziennikarzami NRD, człowiek z ulgą i radością konstatuje: są inni Niemcy. Inni niż ci, których, niestety, poznaliśmy na własnej skórze" 58 — pisał Kazimierz Kąkol, relacjonujący proces Eichmanna dla polskiej prasy. Słowa Kąkola nie są bez znaczenia, biorąc pod uwagę silnie zakorzeniony w polskiej świadomości narodowej resentyment antyniemiecki, spotęgowany doświadczeniem niedawnej wojny i okupacji oraz niepewności o trwałość granicy wzdłuż Odry i Nysy Łużyckiej ${ }^{59}$. Wiara w inne, antyfaszystowskie Niemcy była zasadniczym motywem warunkującym powrót — z zagranicy bądź „wewnętrznej emigracji" - wielu prominentnych artystów, intelektualistów czy akademików o orientacji prolewicowej, takich jak: Alexander Abusch, Bertolt Brecht, Willi

55 Por. J. Herf, Divided Memory..., s. 182.

56 Ibidem, s. 184.

57 Ibidem, s. 181

58 Por. K. Kąkol, Adolfa Eichmanna droga do Bejt Haam, Warszawa 1962, s. 288-296.

59 Por. m.in. S. Anderson, A Cold War in the Soviet Bloc: Polish-East German Relations, 1945-1962, Boulder 2001. 
Bredel, Stephan Hermlin, Stefan Heym, Victor Klemperer, Theodor Plievier, Bodo Uhse, Erich Weinert, Friedrich Wolf czy Arnold Zweig ${ }^{60}$.

W NRD od samego początku działali i tworzyli przedstawiciele młodszego pokolenia, rzeczonej „drugiej generacji Hitlerjugend”, m.in. Christa Wolf czy Heiner Müller; równie gorliwi antyfaszyści jak ich poprzednicy, choć nieco bardziej autokrytyczni wobec rzeczywistości polityczno-społecznej NRD ${ }^{61}$. Co szczególnie istotne, wykładnia wschodnioniemieckich komunistów znalazła podatny grunt poza członkami bloku wschodniego bądź zaprzyjaźnionymi krajami w Afryce, Azji czy Ameryce Południowej, m.in. wśród brytyjskich laburzystów ${ }^{62}$, radykalnej lewicy w $\mathrm{RFN}^{63}$ - do dzisiaj przedmiotem sporów jest charakter i stopień relacji między Stasi a Grupą Baader-Meinhof — czy wrogich Izraelowi państw muzułmańskich ${ }^{64}$.

$\mathrm{Z}$ jednej strony, omawiana tu pokrótce niemiecko-niemiecka wojna podjazdowa świadczyła o sekciarskiej tożsamości wschodnioniemckich komunistów; myśleniu w kategoriach swój-wróg; przekonaniu, że jest się dysponentem jednej jedynej prawdy - elementy te występowały też w podawanych we wstępie definicjach antyfaszyzmu według Judta i Thompsona. Z drugiej zaś strony — wiernie odzwierciedlała totalność (tudzież kompleksowość) narracji antyfaszystowskiej, jej prewencyjny i dyscyplinujący charakter. Antyfaszyzm nie ograniczał się bowiem jedynie do sfery symboliki, nie był pustym pojęciem z historiografii czy historii idei. Miał jasno określone przełożenie praktyczne. Stanowił punkt odniesienia dla przeprowadzanych reform, relacji społecznych, kontaktów ze światem zewnętrznym, bieżących decyzji politycznych. NRD samookreśliło się przecież

60 Por. J. Rodden, Repainting the Little Red Schoolhouse: A History of Eastern German Education, 1945-1995, Oxford-New York 2002, s. 45.

61 O sylwetce i twórczości Ch. Wolf por. m.in. H. Bridge, Women's Writing and Historiography in the GDR, Oxford-New York 2002, s. 57-89; D. Tate, Shifting Perspectives: East German Autobiographical Narratives Before and After the GDR, Rochester-New York 2007, s. 194-235; K. Webb, Christa Wolf Obituary, https://www.theguardian.com/books/2011/dec/01/christa-wolf (dostęp: 30.06.2016); O Heinerze Müllerze por. m.in. J. Kalb, The Theather of Heiner Müller, New York 2001; I. Stokfiszewski, Testament Müllera, http://www.encyklopediateatru.pl/artykuly/70226/ testament-mllera (dostęp: 30.06.2016). To, że twórcy ci cieszą się niesłabnącą popularnością po 1989/1990 r., świadczy o uniwersalności ich dorobku, pomimo poparcia dla niedemokratycznego reżimu.

62 Por. S. Berger, N. LaPorte, Friendly Enemies: Britain and the GDR, 1949-1990, New York-Oxford 2010; S. Berger, N. LaPorte, In Search of Antifascism: The British Left's Response to German Democratic Republic during the Cold War, „German History” 26, 2008, z. 4, s. 536-552; A. Glees, The Stasi Files: East Germany's Secret Operations Against Britain, New York 2004.

63 Por. J. Herf, Divided Memory..., s. 334-335 i 348-350; D. Diner, op. cit., s. 128; J. Herf, Undeclared Wars with Israel: East Germany and the West German Far Left, 1967-1989, New York 2016; B. Röhl, Zabawa w komunizm! Ulrike Meinhof, Klaus Rainer Röhl i prawdziwe korzenie Nowej Lewicy (1958-1968), Warszawa 2007; G. Aly, Unser Kampf '68: gniewne spojrzenie w przeszłość, Warszawa 2010.

64 Por. J. Herf, Divided Memory..., s. 190-200; A. Timm, Views on Zionism and Israel in East Germany, „Shofar: An Interdisciplinary Journal of Jewish Studies” 18, 2000, nr 3, s. 93-109. 
jako „antyfaszystowskie państwo”. Antyfaszyzm stanowił jego „mit fundacyjny" ${ }^{15}$. Niezbędnym warunkiem jego powstania było pozbawienie władzy owych „najbardziej reakcyjnych, imperialistycznych i szowinistycznych elementów kapitału finansowego", które miał na myśl G. Dymitrow. Nieokreśloność tego terminu powodowała, iż można nim było obdarzyć niemal każdego, w tym osoby uznane za przeciwników reżimu bądź opozycję wewnątrzpartyjną. Tam, gdzie po zakończeniu wojny siły kapitalizmu zostały nadwątlone, lecz nie do końca przezwyciężone - jak w niesowieckich strefach okupacyjnych i późniejszym NRD — występowały okoliczności umożliwiające powrót do faszyzmu. „Przez wzgląd na swą antyfaszystowską proweniencję [NRD - S.P.] rozumiało samą siebie jako antytezę zarówno Trzeciej Rzeszy, jak i Republiki Federalnej, podatnych na nawrót faszystowskich rządów z racji panującego tam kapitalistycznego układu społecznego"66 — pisał D. Diner. Samo istnienie NRD stanowiło zatem antidotum uniemożliwiające realizację takiego scenariusza. Nie powinno więc dziwić to, że w propagandzie NRD wzniesiony w $1961 \mathrm{r}$. mur oddzielający zachodnią i wschodnią część Berlina nosił nazwę „,antyfaszystowskiego wału ochronnego" (antifaschistischer Schutzwall) ${ }^{67}$.

Konfrontacyjna postawa względem RFN, nawet jeżeli rzeczywiście była to strategia „obrony przez atak”, niewątpliwie wzmacniała tożsamość NRD jako państwa i „nowego narodu”. Niemcy ze Wschodu nieustannie porównywali się bowiem ze swymi zachodnimi sąsiadami i choć miernik dobrobytu wypadał na niekorzyść NRD — pomimo starań władz, by poziom konsumpcji utrzymywał się na maksymalnie wysokim poziomie (w tym aspekcie przywódcy komunistyczni, a zwłaszcza Erich Honecker, który w 1971 r. zastąpił Ulbrichta na stanowisku przewodniczącego SED, niewiele różnili się od Hitlera) — odczuwali moralną wyższość z racji rzekomej „ofiary” w walce z hitleryzmem i braku nazistów w rządzie. Stawianie RFN w jednym rzędzie z III Rzeszą, a Globkego z Hitlerem lub Eichmannem, choć efektowne od strony propagandowej, nie było niczym innym jak trywializowaniem historii, na co słusznie zwraca uwagę Diner ${ }^{68}$. Podobnego nadużycia dokonują niektórzy zwolennicy teorii „totalitaryzmu”, przeważnie

65 D. Diner, op. cit., s. 128. Jak pisze Henry Tudor: „Wiele mitów politycznych można określić jako mity fundacyjne. Opowiadają historię o tym, jak wytworzyła się dana polityczna społeczność. Choć mitów tych jest już dostatecznie wiele we współczesnych czasach (w szczególności, gdy idzie o państwa powstałe w wyniku rewolucyjnych wstrząsów czy wojen o niepodległość), najlepsze przykłady można znaleźć w literaturze politycznej klasycznej starożytności [np. mit o założeniu Rzymu, szczegółowo omawiany przez Tudora - S.P.]" (por. H. Tudor, Political Myth, London-Basingstoke 1972, s. 65-90).

66 D. Diner, op. cit., s. 127.

67 Por. m.in. A. Wolff-Powęska, Niemiecka Republika Demokratyczna wobec nazistowskiej przeszłości..., s. 55; S. Kattago, op. cit., s. 88; P. Major, Behind the Berlin Wall: East Germany and the Frontiers of Power, Oxford-New York 2010.

68 D. Diner, op. cit., s. 128. 
o skrajnie antykomunistycznych poglądach, niedostrzegający zasadniczych różnic między obu systemami — „brunatnym” i ,czerwonym”69.

Pełnej racji nie mają zarówno ci przedstawiający NRD jako Stasiland - nawiązując do tytułu głośnej publikacji Anny Funder z 2003 r. — gdzie zasadniczy akcent pada na rzekomą wszechwładzę Stasi i masowej inwigilacji społeczeństwa przez naczelny organ bezpieczeństwa państwa, ani liczne zapewnienia byłych mieszkańców NRD, że wiedli oni „,zupełnie normalne życie" ${ }^{70}$. Po „terapii szokowej", z jaką dla wielu z nich wiązały się gwałtowne przemiany okresu Die Wende (,przełomu”/,zmiany”) z lat 1989/1990, ich doświadczenie stanowić będzie podstawę tzw. Ostalgie - nostalgicznej narracji za czasami bezpowrotnie minionymi, utożsamianych w pierwszej kolejności ze specyficznym folklorem ${ }^{71}$; gwarancją pracy i bezpieczeństwa socjalnego; przedkładaniem wspólnotowości nad indywidualizmem - czego wyrazistą demonstracją był masowy, obligatoryjny, quasi-militarny wręcz charakter enerdowskich organizacji młodzieżowych $^{72}$. Najbliżej „prawdy” wydają się być ci, którzy w swoich badaniach łączą obydwie te perspektywy, np. Mary Fulbrook - autorka tezy o systematycznym zawłaszczaniu przez państwo kolejnych obszarów życia społecznego (od aparatu przemocy po organizację wolnego czasu ${ }^{73}$ ) przy milczącej akceptacji ze strony większości społeczeństwa, które przyjęło oferowaną przez władzę upraszczającą, przesadnie apologetyczną interpretację przeszłości: zarówno tej niedawnej, jak i całkiem odległej. Antyfaszyzm i postrzeganie NRD jako sumy rewolucyjnych, najbardziej postępowych procesów w niemieckiej historii zapewniało niezbędne minimum „bezpieczeństwa ontologicznego”. Zdaniem jego twórcy, Anthony’ego Giddensa, „sformułowanie to odnosi się do ufności, z jaką większość istot ludzkich traktuje ciągłość własnej tożsamości oraz stałość otaczającego je środowiska

69 Por. J. Herf, Post-Totalitarian Narratives in Germany: Reflections on Two Dictatorships after 1945 and 1989, „Totalitarian Movements and Political Religions” 9, June-September 2008, nr 2-3, s. 161-186; K. Wóycicki, op. cit., s. 66-73.

70 M. Fulbrook, The People's State: East German Society from Hitler to Honecker, New Haven-London 2005, s. 8,6/1004 [mobi].

71 Najbardziej rozpoznawalnymi elementami tego folkloru są m.in. samochody marki Wartburg i Trabant — drugi z nich pojawił się w sesji zdjęciowej do okładki albumu Achtung Baby zespołu U2 (1991), stanowił też jeden z elementów scenografii na trasie koncertowej ZOOtv/Zooropa Tour (1992-1993) — charakterystyczny symbol stojącego/maszerującego ludzika z kapeluszem na sygnalizacji świetnej dla pieszych (tzw. Ampelmännchen), filmy DEFA, produkcje telewizyjne stacji Deutscher Fernsehfunk (DFF), w tym popularna również w Polsce animacja Piaskowy dziadek (Unser Sandmännchen), nadawana w latach 1959-1991. O zjawisku ostalgii por. m.in. K. Wóycicki, op. cit., s. 94-101; C. Hyland, Ostalgie doesn't fit!: Individual Interpretations of and Interactions with Ostalgie, [w:] Remembering and Rethinking the GDR, red. A. Saunders, D. Pinfold, Routledge, London-New York 2013, s. 101-115.

72 Por. J. Rodden, op. cit., s. 63-70.

73 Por. M. Fulbrook, The People's State..., s. 6-12. 
społecznego i materialnego”74. „Kto kontroluje przeszłość, ten ma władzę na przyszłością" - głosiło z kolei hasło na murach Ministerstwa Prawdy w słynnej powieści George'a Orwella Rok 1984, które w pewnym stopniu odnosiło się także do realiów NRD. Podporządkowanie sobie historyków ${ }^{75}$ uznane zatem zostało za konieczne zabezpieczenie drogi do komunizmu, który na przełomie lat 60. i 70.

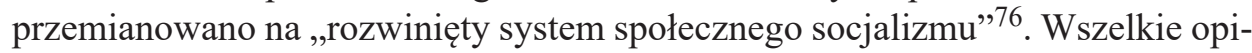
nie uznane za odbiegające od „oficjalnie obowiązujących” były zaś stanowczo pacyfikowane, gdyż zagrażały istnieniu państwa opartego na specyficznej teorii historii — w tym aspekcie NRD stało na wyraźnie słabszej pozycji niż pozostałe państwa komunistycznego bloku wschodniego, które mogły odwoływać się do kilkusetletniej historii swego istnienia ${ }^{77}$. Wspomniana już totalność narracji antyfaszystowskiej okazała się również słabością. Gdy nastąpiła jej erozja, wyraźnemu osłabieniu uległy również fundamenty państwa. Nie wydaje się więc zbytnio przesadzona teza, iż NRD trwać mogło tak długo jak enerdowski antyfaszyzm.

$* * *$

Zwycięstwo ZSRR nad III Rzeszą nie oznaczało końca narracji antyfaszystowskiej. Nie spełnił się zatem scenariusz zakładający jej unieważnienie po zachwianiu się ponad 20-letniego układu sił, przypominającego quasi-dialektyczną rywalizację, w której obydwie strony przeciwstawiały się sobie i uzupełniały nawzajem. Można zaryzykować wręcz tezę, że po 1945 r. antyfaszyzm zyskał „drugi oddech”, czego potwierdzeniem jest sytuacja w NRD, gdzie wypełniał on szczególnie istotną rolę — źródła legitymizacji enerdowskiego państwa, jego założycielskiego (Wolff-Powęska) tudzież fundacyjnego (Diner) mitu - mitu odnoszącego się do ogółu obywateli, niewyłącznie przedstawicieli elit i/lub władzy. Częściowo rekompensował on niedogodności związane z niedemokratycznością systemu bądź całkowitą zależnością od Sowietów (wyrażoną m.in. w powielaniu rozwiązań ideologiczno-instytucjonalnych, wykonywaniu zobowiązań sojuszniczych, akcentowaniu pewnych kwestii bądź pomijaniu tych uchodzących za problematyczne ${ }^{78}$ ). Opanowując niemal do perfekcji praktykę pozorowania (np.

74 „Bezpieczeństwo ontologiczne odnosi się do »bycia« czy też, mówiąc w kategoriach fenomenologicznych, »bycia w świecie«" - kontynuuje dalej Giddens. — „Jest to jednak bardziej zjawisko natury emocjonalnej niż kognitywnej, zakorzenione w nieświadomości”. Por. A. Giddens, Konsekwencje nowoczesności, Kraków 2008, s. 65-66.

75 Por. m.in. K.H. Jaraush, The Failure of East German Antifascism: Some Ironies of History as Politics, „German Studies Review” 14, 1991, nr 1, s. 85-101; A. Wolff-Powęska, Niemiecka Republika Demokratyczna wobec nazistowskiej przeszłości..., s. 61-62.

76 K. Wóycicki, op. cit., s. 89.

77 D. Diner, op. cit., s. 128-129.

78 Jedną z takich kwestii było istnienie tzw. sowieckiego obozu specjalnego nr 2 (Speziallager 2), w którym w latach 1945-1950 przetrzymywano głównie pomniejszych funkcjonariuszy 
w postaci Scheindemokratie), manipulacji na faktach, mitologizacji, hiperbolizacji, ujmowania złożonej rzeczywistości w uproszczonych kategoriach „swój-obcy”, „przyjaciel-wróg”, przywódcy SED umiejętnie podtrzymywali społeczeństwo w tytułowym ,złudnym nieuwikłaniu”, w którym mocno pragnęło ono trwać.

Bezpośrednio po 1945 r. dla Niemców, niezależnie od wieku czy miejsca zamieszkania, sprawę zasadniczej wagi stanowiło ustosunkowanie się do trudnego dziedzictwa III Rzeszy. W okresie 1945-1989/1990 oba państwa niemieckie przyjęły odmienną strategię. O ile RFN obrało żmudną i długoletnią metodę ,internalizacji” przeszłości, tj. uznania okresu 1933-1945 za istotny fragment historii Niemiec i próbę jej przezwyciężenia/pogodzenia się z nią (tzw. Vergangenheitsbewältigung) - początkowo niechętnie, ze znaczącymi osiągnięciami w kolejnych dekadach - o tyle w NRD III Rzesza uległa ,uniwersalizacji” jako tragiczny, acz niezbędny fragment większej całości (walka klas, akumulacja kapitału), poprzedzający nastanie komunizmu, za który proletariat wschodnioniemiecki nie ponosił żadnej odpowiedzialności. Przeciwnie, celebrowano pamięć zwycięskiego oporu przeciw faszyzmowi. Jego manifestacją były m.in.: przypadający corocznie na drugą niedzielę września Międzynarodowy Dzień Ofiar Faszyzmu bądź kult osób stylizowanych na „świeckich świętych” komunizmu, jak E. Thälmann. W rzeczywistości wyobrażenia te oparto na nieprawdziwych przesłankach. Co prawda, komuniści ponieśli znaczącą ofiarę z rąk narodowego socjalizmu - Mary Nolan podaje liczbę 150 tys. osób aresztowanych i 20 tys. zabitych ${ }^{79}$. Byli też pierwszą społecznością, która stawiła zorganizowany opór cywilny bądź militarny. Miał on z reguły oddolny i spontaniczny charakter ${ }^{80}$, niemniej nie odegrał jednak żadnej istotnej roli w obaleniu III Rzeszy. To robotnicy masowo poparli NSDAP w $1933 \mathrm{r}$., to z ich nastrojami Hitler musiał się liczyć, oni zaś okazywali mu wierność aż do maja 1945 r., ignorując w swojej większości dramatyczne apele przywództwa KPD w kraju lub za granicą. Z życiorysów „,bojowników/męczenników walki z faszyzmem" usuwano co bardziej kontrowersyjne fakty — w hagiograficznych książkach czy filmach o Thälmannie nie sposób znaleźć informacji o tym, że wikłając

nazistowskich i część osób uznanych za wrogie ustrojowi komunistycznemu (socjaldemokratów, liberałów, chrześcijańskich demokratów, dysydentów wewnątrz KPD/SED i pozostałych) — łącznie ok. 32 tys. osób w przeciągu pięciu lat, spośród których przybliżona liczba 7 tys. osób zmarła w wyniku chorób i głodu. Odkrycie ich masowych grobów w połowie lat 80. zostało przemilczane w enerdowskich mediach. Po 1990 r. zwołano specjalną komisję historyków pod przewodnictwem Eberharda Jäckela celem zweryfikowania informacji związanych z obozem, rozpowszechnianych w latach 1945-1990. Ustalono, iż w różnych okresach czasu pełnił on trzy odmienne funkcje: 1) nazistowskiego obozu koncentracyjnego w latach 1937-1945; 2) sowieckiego obozu internowania w latach 1945-1950; 3) obozu-pomnika w latach 1945-1990, upamiętniającego antyfaszystowską narrację o powszechnej i zwycięskiej walce niemieckiej klasy robotniczej z hitleryzmem. Por. m.in. Soviet Special Camp No. 2, https://www.buchenwald.de/en/73/ (dostęp: 30.06.2016); A. Moaz, op. cit., s. 6-10; S. Kattago, op. cit., s. 89-92; Z. Wóycicka, op. cit., s. 185-186.

79 M. Nolan, Antifascism under Fascism: German Visions and Voices, „New German Critique", January 1996, z. 67, s. 41.

${ }^{80}$ Por. A. Merson, Communist Ressistance in Nazi Germany, London 1986, s. 304-312. 
się w bratobójczą rywalizację z SPD, znacząco ułatwił nazistom dojście do władzy. Heroizm tychże postaci — niezależnie od tego, czy był on autentyczny czy też wydumany - często nie współgrał z ich późniejszą karierą urzędników/biurokratów i mieszczańską rzeczywistością $\mathrm{NRD}^{81}$. W publikacji poświęconej różnym metodom instrumentalizacji pamięci o byłych członkach Międzynarodowych Brygad w NRD Josie McLellan przytacza następującą obserwację przyjaciela syna weterana wojny w Hiszpanii, B. Ohsego:

On [jego ojciec] był bohaterem francuskiego ruchu oporu [...] i walczył w Hiszpanii, a teraz zawładnęły nim praca w biurze i domatorstwo. Jego jedynymi zmartwieniami wydawały się być jego dzieci, pielęgnacja roślin i najświeższe doniesienia kulturalne [...]. Gdy wojna się kończy, gdy nasi ojcowie powracają z wygnania, przestają być artystami i wojownikami, przekształcają się w pomniejszych, wiernopoddańczych księgowych ${ }^{82}$.

Nawet jeżeli podstawa antyfaszyzmu oparta była na prawdzie $-\mathrm{z}$ jaką wiążą się świadectwa osób takich jak Ohse - została skutecznie rozmyta poprzez rozszerzenie jej na resztę społeczeństwa, które w latach 1933-1945 cechowała raczej bierność.

\section{$* * *$}

Zasadnicza część analizy poświęcona została mechanizmom, praktykom czy sposobom myślenia nieustannie obecnym w codzienności NRD, do znużenia powtarzanym na uroczystościach państwowych czy w przekazie medialnym. $\mathrm{Z}$ racji ograniczonego miejsca oraz tego, iż zagadnienie to zasługuje na osobną rozprawę, niewiele uwagi poświęcono dotychczas kwestiom nieuwzględnionym w oficjalnym dyskursie, a w szczególności braku pamięci o Holokauście. Zagłada Żydów stanowiła bowiem wyzwanie dla „pokrzepiającej” narracji oferowanej przez antyfaszyzm. Jej pomijanie przeczyło tezie o NRD jako „zwycięzcy historii"; państwie, które w przeciwieństwie do zachodniego sąsiada, skutecznie i w imponująco szybkim czasie uporało się z ciężarem przeszłości. Było kolejnym

81 J. McLellan, op. cit., s. 94.

82 Jak zauważa K. Bachmann: „Konstrukcja przeszłości opiera się na myśleniu w kategoriach grupowych i narodowych [...] Troską ich wszystkich są głównie dobra materialne, przezwyciężenie biedy i obrona tradycyjnej moralności opartej na modelu wielodzietnej rodziny i patriarchalne, wertykalnie zorganizowane społeczeństwo, którego głównymi wartościami są posłuszeństwo, szacunek wobec starszych, respekt przed władzą, pracowitość. Ideologia komunistyczna nie zmienia tej hierarchii wartości, lecz ją wykorzystuje. Wkrótce komuniści enerdowscy stają się jeszcze bardziej drobnomieszczańscy, zachowawczy i autorytarni niż ich wrogowie klasowi na Zachodzie" (K. Bachmann, op. cit., s. 55). Thomas Lindenberger zauważa z kolei, iż pomimo haseł o solidarności z ,zaprzyjaźnionymi” krajami Trzeciego Świata, zdecydowana większość społeczeństwa nie tolerowała małżeństw bądź związków obywateli NRD z osobą o odmiennym kolorze skóry, pochodzącą spoza europejskiej wspólnoty kulturowej; T. Lindenberger, Tacit Minimal Consensus: The Always Precarious East German Dictatorship, [w:] Popular Opinion in Totalitarian Regimes..., s. 216. 
złudzeniem. Uniwersalizująca interpretacja dziejów nie uwzględniała narodowości ofiar $^{83}$ oraz wszelkich wyjaśnień wychodzących poza ortodoksyjną wykładnię marksizmu-leninizmu. W opinii D. Dinera, poza polem widzenia znalazły się te kategorie osób, które uśmiercono nie z powodu ich zaangażowania w ruch oporu, lecz tego, iż w myśl Ustaw norymberskich z 1935 r. uznano ich za Żydów. Jak pisał Diner:

antyfaszystowska interpretacja narodowosocjalistycznej przeszłości oraz wyciągnięte z niej polityczne wnioski w zasadzie uniemożliwiały pamięć o negatywnym, radykalnym rdzeniu masowej eksterminacji - eksterminacja wychodząca poza ekonomiczną eksploatację czy politycznie umotywowaną opresję została zignorowana. Antyfaszyzm pozbawił Auchwitz jego istoty ${ }^{84}$.

Antysemityzm zepchnięto zaś do rangi „nadprogramowego epifenomenu” 85 (superstructural epiphenomenon), posługując się określeniem J. Herfa. Nierzadko postrzegany był jako ,narzędzie kapitalistów mające na celu dezorientację, podział i osłabienie klasy robotniczej, nie jako ideologię o genezie i oddziaływaniu niezależnym od kapitalizmu" ${ }^{\text {86 }}$. Odmienność doświadczeń ze strony więźniów politycznych i Żydów doprowadziła do zjawiska hierarchizacji. Tych pierwszych gloryfikowano, podczas gdy drudzy uchodzili za „bezwolne ofiary”, niegodne statusu „bojowników” bądź „męczenników” z racji niepodjęcia walki zbrojnej ${ }^{87}$. $\mathrm{Z}$ tego powodu pozbawiono ich też prawa do odszkodowań. Kolejnym zarzutem stawianym wobec Żydów były ich rzekomo ścisłe związki z wielkim kapitałem — jedna z wielu antysemickich klisz, które przetrwały klęskę III Rzeszy. Za największą zbrodnię Hitlera uznano nie Endlösung, lecz wojnę z ZSRR. W takim kontekście bitwa pod Stalingradem stała się „punktem wyjścia do lepszej, nowej przyszłości Niemiec" $" 88$, cementującym sojusz niemiecko-radziecki.

$\mathrm{W}$ ramach KPD/SED głosy podkreślające usytuowanie Zagłady w centrum należały do wyjątków. Jedynym działaczem ze ścisłego kierownictwa obu partii, który „kwestię żydowskiego cierpienia przesunął z peryferii do centralnego miejsca w narracji komunistycznego antyfaszyzmu — pierwszy i jedyny raz w jej historii”"89, był Paul Merker. W przeciwieństwie do „Moskwian” wojnę spędził on w Meksyku, gdzie obracał się wśród liczącej ok. 25 tys. osób społeczności żydowskiej, w więk-

83 Symptomatyczny wydaje się przy tym fakt, iż w miejscach, gdzie narodowość ofiar została uwzględniona, np. na terenie obozu Auschwitz-Birkenau, z racji kolejności alfabetycznej Żydów zazwyczaj wymieniano na samym końcu listy ofiar, za Francuzami, Polakami czy obywatelami ZSRR; również pawilon żydowski w Auschwitz-Birkenau usytuowany był na poboczu.

${ }^{84}$ D. Diner, op. cit., s. 130.

85 J. Herf, Divided Memory..., s. 14.

86 Ibidem, s. 16.

87 Por. m.in. S. Kattago, op. cit., s. 85-86; A. Wolff-Powęska, Niemiecka Republika Demokratyczna wobec nazistowskiej przeszłości..., s. 57; J. Herf, Divided Memory..., s. 164-165.

88 A. Wolff-Powęska, Niemiecka Republika Demokratyczna wobec nazistowskiej przeszłości..., s. 61 .

89 J. Herf, Divided Memory..., s. 40. 
szości o orientacji lewicowej, co wywarło niemały wpływ na jego pisarstwo. Jeden z napisanych tam tekstów zatytułował Hitlers Antisemitismus und Wir (Hitlerowski antysemityzm i my). Podkreślał $\mathrm{w}$ nim $\mathrm{m}$.in. autonomiczną pozycję antysemityzmu (,najciemniejszej reakcji”), jednakowość sytuacji Żydów i klasy robotniczej, konieczność odbudowy społeczności żydowskiej po zakończeniu wojny — poprzez szeroko zakrojoną pomoc materialną, zwiększenie autonomii, nie wykluczał też ewentualności utworzenia odrębnego państwa. Poglądy te sprowadziły na niego oskarżenie o agenturę i 8-letnią karę więzienia (anulowaną po niespełna roku) ${ }^{90}$.

Co paradoksalne, swojej żydowskości ani pamięci o Zagładzie z reguły nie kultywowali wysoko postawieni politycy SED — tacy jak wspomniani już A. Norden czy K.F. Kaul — bądź intelektualiści (A. Abusch, A. Seghers, A. Zweig i inni). Pewną rekompensatę odnaleźli zapewne w antyfaszyzmie, angażując się namiętnie w misję jego szerzenia. Możliwe, iż częściowo wynikło to z efektu wyparcia, po części dlatego, iż „dla osób, które ledwo przeżyły niewyobrażalne męki, identyfikacja $\mathrm{z}$ antyfaszyzmem była sposobem na przezwyciężenie uderzająco arbitralnego cierpienia, sposobem przejęcia kontroli nad własnym losem, retrospektywną zemstą na nieludzkim wrogu" - jak stwierdził belgijski historyk Pieter Lagrou ${ }^{91}$.

Jeszcze w połowie lat 70 . Ch. Wolf, powieściopisarka nieżydowskiego pochodzenia, której bliżej do Seghers niż Merkera, wypowiadała się o Auschwitz jako abstrakcji: „Jest to bowiem nie do zniesienia, gdy przy słowie Auschwitz trzeba również pomyśleć słówko $» j a$ — — $» j a$ « trybie warunkowym czasu przeszłego niedokonanego. »Byłbym zrobił«. »Mógłbym zrobić«. »Byłbym usłuchał«. »Mógłbym usłuchać«"92.

Zwrot w myśleniu o Zagładzie nastąpił pod koniec następnej dekady w związku z uroczystościami 50. rocznicy Kristallnacht. Choć utrzymano je w obowiązującej antyfaszystowskiej tonacji i w pewnym sensie stanowiły odpowiedź na wizerunkową katastrofę, jaką dla RFN okazała się wspólna wizyta Helmuta Kohla i Ronalda Reagana na cmentarzu poległych niemieckich wojskowych w Bitburgu w maju 1985 r. ${ }^{93}$, tragiczne wydarzenia z 9-10 listopada 1938 r. po raz pierwszy wyparły rewolucję listopadową 1918 r., która do tej pory zajmowała większość uwagi ${ }^{94}$. Kolejnym krokiem była uchwała pierwszej demokratycznie wybranej Izby Ludowej z 12 kwietnia 1990 r., uznającej (przy 379 głosach za i 21 wstrzymaniach się od głosu) odpowiedzialność NRD za zbrodnie nazistowskie, gotowość

90 Ibidem, s. 40-68. Por. też. J. Herf, East German Communists and the Jewish Question: The Case of Paul Merker, „Journal of Contemporary History” 29, October 1994, nr 4, s. 627-661.

91 P. Lagrou, The Legacy of Nazi Occupation: Patriotic Memory and National Recovery in Western Europe, 1945-1965, New York 2000, s. 260; cyt. za Z. Wóycicka, op. cit., s. 162.

92 Ch. Wolf, Wzorce dzieciństwa, przeł. S. Błaut, Warszawa 1986, s. 286; cyt. za Ch. Meier, Od Aten do Auschwitz. Rozważania nad kondycja historii, przeł. A. Artwińska, Poznań 2013, s. 153.

93 Założeniem tej wizyty było upamiętnienie 40. rocznicy zakończenia II wojny światowej. Spotkała się ona z krytyką w Stanach Zjednoczonych i pozostałych krajach po odkryciu, że w znaczącej części grobów pochowani są członkowie Waffen-SS. Por. J. Herf, Divided Memory..., s. 350-354.

94 Por. S. Kattago, op. cit., s. 103-104 i 106-110. 
do wypłacenia odszkodowań ${ }^{95}$ i nawiązania stosunków dyplomatycznych z Izraelem $^{96}$. W ostatniej fazie swego istnienia, po 40 latach nieustannego umywania rąk, obywatele NRD, głosami reprezentantów, przyjęli współodpowiedzialność za Holokaust. W ponownie zjednoczonych Niemczech Ossi, prócz konfrontacji ze świeżą pamięcią komunizmu, musieli zmierzyć się z jeszcze jednym zadaniem skorygowaniem złudnego wyobrażenia o latach 1933-1945 z lat 1945-1989/1990.

\section{Bibliografia}

\section{Monografie, publikacje zwarte}

Bachmann K., Dtugi cień Trzeciej Rzeszy. Jak Niemcy zmieniali swój charakter narodowy, Wrocław 2005.

Bridge H., Women's Writing and Historiography in the GDR, Oxford-New York 2002.

Conradi, P.J., A Very English Hero: The Making of Frank Thompson, London 2012.

Fulbrook M., The People's State: East German Society from Hitler to Honecker, New Haven-London 2005.

Giddens A., Konsekwencje nowoczesności, Kraków 2008.

Heiduschke S., East German Cinema: DEFA and Film History, New York-London 2013.

Herf J., Divided Memory: The Nazi Past in the Two Germanies, Cambridge-London 1997.

Judt T., Postwar: A History of Europe Since 1945, New York 2005.

Kattago S., Ambigious Memory: The Nazi Past and German National Identity, Westport 2001.

Leonhard W., Dzieci Wolności, Warszawa 2013.

McLellan J., Antifascism and Memory in East Germany: Remembering the International Brigades 1945-1989, Oxford 2004.

Meier Ch., Od Aten do Auschwitz. Rozważania nad kondycją historii, przeł. A. Artwińska, Poznań 2013.

Merson A., Communist Ressistance in Nazi Germany, London 1986.

Münkler H., Mity Niemców, Warszawa 2013.

Olsen J.B., Tailoring Truth: Politicizing the Past and Negoriating Memoryn in East Germany, 1945 1990, New York-Oxford 2015.

Rodden J., Repainting the Little Red Schoolhouse: A History of Eastern German Education, 19451995, Oxford-New York 2002.

Tudor H., Political Myth, London-Basingstoke 1972.

Wolff-Powęska A., Pamięć — brzemię i uwolnienie. Niemcy wobec nazistowskiej przeszłości (19452010), Poznań 2011.

Wóycicka Z., Przerwana żałoba. Polskie spory wokót pamięci nazistowskich obozów koncentracyjnych i zagtady, 1944-1950, Warszawa 2009.

Wóycicki K., Niemiecka pamięć. Rozrachunek z przeszłościa NRD i przemiany niemieckiej świadomości historycznej, Warszawa 2011.

95 W 1956 r. premier Otto Grotewohl z lekceważeniem wypowiadał się o reparacjach wypłacanych Izraelowi przez RFN w ramach tzw. Umowy luksemburskiej z 1952 r., twierdząc, iż Izrael wykorzystuje je w ,walce przeciw niepodległościowym ruchom na Bliskim Wschodzie”; za A. Wolff-Powęska, Niemiecka Republika Demokratyczna wobec nazistowskiej przeszłości..., s. 75.

96 J. Herf, Divided Memory..., s. 364-365. O antysyjonistycznej (= antyizraelskiej) polityce zagranicznej NRD por. ibidem, s. 190-200; J. Herf, Post-Totalitarian Narratives in Germany..., s. $172-174$.

Studia nad Autorytaryzmem i Totalitaryzmem 38, nr 3, 2016

(C) for this edition by CNS 


\section{Artykuły w publikacjach zbiorowych}

Cofino A., The Holocaust as a Symbolic Manual: The French Revolution, the Holocaust, and Global Memories, [w:] Marking Evil: Holocaust Memory in the Global Age, red. A. Goldberg, H. Hazan, New York-Oxford 2015.

Diner D., Vorwort des Herausgebers, [w:] Zivilisationsbruch: Denken nach Auschwitz, red. D. Diner, Frankfurt am Main 1988.

Fulbrook M., Demography, Opportunity or Ideological Conversion? Reflections on the Role of the 'Second Hitler YouthGenerations', or '1929ers' in the GDR, [w:] Popular Opinion in Totalitarian Regimes, red. P. Corner, Oxford-New York 2009.

Herf J., Politics and Memory in West and East Germany since 1961 and in United Germany since 1990, [w:] After Eichmann: Collective Memory and the Holocaust since 1961, red. D. Cesarani, London-New York 2005.

Hyland C., Ostalgie doesn't fit!: Individual Interpretations of and Interactions with Ostalgie, [w:] Remembering and Rethinking the GDR, red. A. Saunders, D. Pinfold, London-New York 2013.

Lindenberger T., Tacit Minimal Consensus: The Always Precarious East German Dictatorship, [w:] Popular Opinion in Totalitarian Regimes, red. P. Corner, Oxford-New York 2009.

\section{Artykuły w czasopismach}

Berger S., LaPorte N., In Search of Antifascism: The British Left's Response to German Democratic Republic during the Cold War, „German History” 26, 2008, z. 4, s. 536-552.

Diner D., On the Ideology of Antifascism, „New German Critique”, January 1996, z. 67, s. 123-132.

Eley G., Legacies of Antifascism: Constructing Democracy in Postwar Europe, „New German Critique", January 1996, z. 67, s. 73-100.

Herf J., East German Communists and the Jewish Question: The Case of Paul Merker, „Journal of Contemporary History" 29, October 1994, nr 4, s. 627-661.

Herf J., Post-Totalitarian Narratives in Germany: Reflections on Two Dictatorships after 1945 and 1989, „Totalitarian Movements and Political Religions” 9, June-September 2008, nr 2-3, s. $161-186$.

Jaraush K.H., The Failure of East German Antifascism: Some Ironies of History as Politics, „German Studies Review" 14, February 1991, nr 1, s. 85-101.

Judt T., The Past is Another Country: Myth and Memory in Postwar Europe, „Deadalus” 121, Fall 1992, nr 4 (Immobile Democracy), s. 83-118.

Lemmons R., 'Germany's Eternal Son': The Genesis of Ernst Thälmann's Myth, 1930-1950, „German Studies Review” 32(2), May 2009, s. 343-356.

Moaz A., RePlacing Memory: The Reorientation of Buchenwald, „Cultural Geographies” 10, 2003, nr 1, s. 1-20.

Nolan M., Antifascism under Fascism: German Visions and Voices, „New German Critique”, January 1996, z. 67, s. 33-55.

Rabinbach A., Introduction: Legacies of Antifascism, „New German Critique”, January 1996, z. 67, s. 3-17.

Remy D., Salheiser A., Integration or Exclusion: Former National Socialists in the GDR, „Historical Social Research" 35, 2010, nr 3 (133), s. 9-21.

Timm A., Views on Zionism and Israel in East Germany, „Shofar: An Interdisciplinary Journal of Jewish Studies" 18, 2000, nr 3, s. 93-109.

Wolff-Powęska A., Niemiecka Republika Demokratyczna wobec nazistowskiej przeszłości, „Przegląd Zachodni” 2001, nr 1, s. 51-82. 


\section{Archiwalia}

ŻIH (Żydowski Instytut Historyczny), 344: Procesy przestępców wojennych, S. 1/599: 5-y dzień procesu przeciwko Biebowowi.

\section{Źródła internetowe}

10 Bloodiest Battles of World War II, http://www.militaryeducation.org/10-bloodiest-battles-ofworld-war-ii/.

Soviet Special Camp No. 2, https://www.buchenwald.de/en/73/.

Webb K., Christa Wolf Obituary, https://www.theguardian.com/books/2011/dec/01/christa-wolf.

\section{ILLUSORY NON-ENTANGLEMENT: THIRD REICH IN ANTIFASCIST NARRATIVE (THE CASE OF GERMAN DEMOCRATIC REPUBLIC)}

\section{Summary}

Antifascism, a historiographical doctrine formulated in the 30 s of the twentieth century by G. Dimitrov, as a result of the Soviet victory over the Third Reich acquired the status of official narrative in countries of the Communist Bloc. It played a particular role in GDR as a primary source of state's legitimization, especially in the early postwar years. Relating on selected historical sources and extensive literature on this subject (to mention, among others, D. Diner, J. Herf, S. Kattago, A. Wolff-Powęska, K. Wóycicki, J. McLellan, M. Fulbrook) I intend to capture the disingenuousness of East German antifascism. Making use of lies, illusion or denial, applying selectiveness on facts or specific way of their interpretation, the GDR authorities managed to integrate the society around a positive yet erroneous myth of victorious mass resistance of the German working class against fascism. What is more, such antifascism played a defensive supervisory function: ,universalizing" the period of 1939-1945 as another stage of long-term rivalry between the proletariat and capitalists it discursively blurred the historical continuity between the GDR and the Third Reich, and sustained the illusion of lack of guilt for the Holocaust which actual (i.e. Jewish) specificity remained unrecognized.

Keywords: Antifascism, GDR, Third Reich, Holocaust, illusion, propaganda.

Szymon Pietrzykowski

e-mail: sz.p@onet.eu 